\title{
World industry in post-industrial society: tendencies and regional shifts ${ }^{1}$
}

\begin{abstract}
The article is devoted to the territorial organization of the manufacturing industry during its transformation from an industrial to a post-industrial phase of development - as one of the most urgent issues of economic geography at the turn of the 21 st century. This period was characterized by the acceleration of human output beyond the industrial system and by the regrouping of its driving forces. Post-industrial development of developed countries in many respects determined the changes in the sectorial, institutional and spatial structures of the global industry. At the same time, industrialization acceleration occurred in developing countries, including at the expense of the "transfer" of productions in a number of industries from more developed countries. This article analyses the changes in the distribution of the manufacturing industry on a global and regional level.
\end{abstract}

Keywords

R\&D • innovation - world industry $\cdot$ manufacturing $\cdot$ spatial structure - regional shifts

(C) University of Warsaw - Faculty of Geography and Regional Studies
Irina A. Rodionova

Department of Regional Economics and Geography, Faculty of Economics, Peoples' Friendship University of Russia e-mail: iarodionova@mail.ru

Received: 1 July 2013

Accepted: 6 November 2013

\section{Introduction}

The world economic community is now a complete system where national economies and other economic entities are united by the international division of labour, worldwide production and sales structure, a global financial system and information network. Globalization contributes to the process of industrialization in the modern world.

First, advanced countries actively transform to the postindustrial stage of development, and developing countries increase their industrial capacity. Second, nowadays the biggest transnational companies with subsidiaries all over the world occupy the main positions in many branches of the world economy. Third, the new technologies of globalization (informative and network) are developing rapidly. Fourth, R\&D progress is distributed worldwide due to the internationalization of research activity and technology transfer. Fifth, significant changes are still taking place under the influence of the world financial and economic crisis.

The analysis is based on a study of statistical data on global industry, macro-regions being the main taxonomic units. It is important to note the complexity of the statistical analysis of industry. In the scientific literature, some differences even exist in the composition of industry branches (mining and manufacturing). The concept of "industry" has no clear definition. The term "industry" means the branch (or sector) of the economy or even the type of activity (now often written about the tourism industry, the entertainment industry, etc.). Until now, the group terms "industrialized economies" and "developed countries" have been used simultaneously and interchangeably. However, the membership of developed and developing country groups («industrialized economies», and «developing and emerging industrial economies») is changing together with a change in geopolitical architecture and economic development. For example, the International Yearbook of Industrial Statistics noted that, since 2000 , the number of industrialized economies had increased from 33 to 57 (Malaysia, Republic of Korea, Singapore and the United Arab Emirates were among the new entrants during this period). Additionally, China is included in the group of developing countries («developing and emerging industrial economies» including China) (United Nations Industrial Development Organization 2013). All these peculiarities must be considered when the situation in the industry is analysed over a long period of time.

Over the past 20 years, the author carried out a study on the development of global industry and its individual sectors. Similar questions on the geography of global industry were considered in another of the author's articles ${ }^{2}$. This work of

'Similar issues have been raised by the author in the following texts: Rodionova (2012) and Rodionova, Kokuytseva (2010)

${ }^{2}$ Rodionova, IA \& Sholudko, AN 2008, 'The transformation of labor and employmen in post-industrial society', Bulletin of Geography: Socio-conomic series, no. 9, pp 21-31. Available from: http://www.degruyter.com/view/j/bog.2008.9.issue--1/v10089 008-0002-x/v10089-008-0002-x.xml?rskey=VxMOUP\&result=1; Rodionova, IA \& Kokuytseva, TV 2010, 'Structural changes of world industry in postindustrial society and structural shifts in the world high-tech production allocation' in Processes of Transformation of Industry and Services in selected countries, no. 16, eds Z Zioło \& T Rachwał, Warsawa-Kraków, pp. 38-51. Available from: http://prace-kgp.up.krakow.pl/ article/view/222/138; Rodionova, IA 2012, 'World manufacturing industry: structural and spatial shifts', Analele Universitatii din Bucuresti (Romania). Geografie, no. LXI/2012, pp. 55-67. Available from: http://www.annalsreview.geo.unibuc.ro/2012/Rodionova.pdf; Rodionova, IA 2013, 'Competitiveness of countries in the world innovation economy: East-Central Europe and Russia', Quaestiones Geographicae no. 32(2), Bogucki Wydawnictwo Naukowe, Poznań, pp. 15-24. Available from: http://geoinfo.amu.edu.pl/ qg/current/quageo-2013-0010.pdf. 
very interesting content and similar to us from the perspective of research methodology is published in the Russian book "Geography of post-industrial industry" (Gorkin 2012). The author focuses on two sets of problems. The first includes a theoretical basis, methodology and research methods of the geography of manufacturing in recent decades. The second set of problems concerns the transformation of the territorial structure of manufacturing in the most "post-industrial" economy of the world - the United States of America. Considerable attention is paid to the refinement and development of such an important branch of knowledge as industrial geography.

The best European and American experts in regional innovations and development are the contributors to another remarkable book (Pelyasov 2012). Success in modern regional economic development is determined by a region's ability to activate synergy effects from a product, process and institutional innovations evolving in localized clusters and regional innovation systems. This book covers the issue of how regional space can be the setting for synergy.

The basis for the study are materials from international publications and analytical reviews: Industrial Development Report, UNIDO; International Yearbook of Industrial Statistics, UNIDO; Science Report, UNESCO; 2012 Global R\&D Funding Forecast; Science and Engineering Indicators, 2010-2012, US. National Science Foundation.

The purpose of this study is a consideration of solutions in relation to the following targets:

- to characterize the position of the regions and countries in the process of changing the picture of "the world's scientific landscape" on the basis of the comparison of statistical data;

- to identify the connection between the innovation process and development leadership in the world economy, global industry and exports of high technology products on the basis of system analysis and mathematical calculations of correlation coefficients;

- to show the main development trends and directions of the global industry before and after the global financial crisis.

Changing the picture of "the world's scientific landscape"

To proceed to the analysis of the situation in the global manufacturing sector, it is necessary to trace the dynamics of the process and describe the current state of the global scientific landscape. Countries' positions in the world economy depend on the way they use the advantages of R\&D. How they are able to use the advantages of the state R\&D depends on their position in the world economy. Currently, knowledge-based industries play a vanguard role in the development of the economy and the social sphere.

It is known that on a highly competitive global market, producers of developed countries are forced to invent more and more competitive products and services. This is associated with the growth of science- and technology-intensive production processes. World practice shows that developed economies who are leaders in technological development are gradually moving their production to less developed countries. Those, in turn, as their technological capacity grows and the cost of the labour force rises, take some of their production out to other countries, which are less technically and economically developed. This is a mechanism of technological innovation diffusion (in the broadest sense of the word). The question is: are there any opportunities for the global periphery countries to perceive and develop technologies that can be transferred there from advanced countries? In this way, developing countries participate in the redistribution of the global product - some to a greater, others to a lesser extent (Rodionova 2009; Rodionova, Kokuytseva 2010; Rodionova 2012).
Determinants of innovative growth and development in the world show that the spatial disparities of the socio-economic development of countries have led to the polarization of R\&D and, on the whole, changed the picture of the modern world's "scientific landscape" (Galkin, Rodionova 2013).

According to the report "2012 Global R\&D Funding Forecast", global R\&D investment will increase to US $\$ 1.5$ trillion in 2013 (in 2008 - US\$1.15 trillion) (Battelle \& R\&D Magazine 2013). Within these predictions, the share of developed countries still accounts for over $70 \%$ of the world total. The group of developed countries also constitutes over $60 \%$ of the global total of researchers in R\&D, and produces about $70 \%$ of the world's scientific publications. In other words, through the "North - South" divide (developed developing countries), the contrasts are retained.

Three main areas of research were formed: North American, European, and East Asian. In addition, the transformation of a three-dimensional space of R\&D (USA - EU - Japan) to a fourdimensional space (USA - EU - China - Japan) took place.. The most rapidly evolving research and scientific-industrial activities are noted in Asia and especially in China (Galkin, Rodionova 2013; Rodionova 2013).

According to UNESCO, in 2012, the share of the USA in global spending on R\&D was about $36 \%$, while the share of Europe was over $24 \%$. The share of Asia increased to $37 \%$. The share of GDP on R\&D spending ranged from $0.4 \%$ in Africa to $2.1 \%$ in the European region (in the U.S. - about $2 \%$ ). The share of expenditure on R\&D in the structure of global GDP is $2.15 \%$, with a double gap index between the economically developed and developing countries (Battelle \& R\&D Magazine 2012).

In terms of R\&D expenditures, in 2012, the following countries were the leaders: the USA ( $31 \%$ of global spending - US $\$ 436$ billion), China (14\% - about US $\$ 200$ billion), Japan (about US $\$ 160$ billion), and Germany (over US $\$ 90$ billion). The eighth, ninth and twelfth positions are occupied by India, Brazil and Taiwan. Russia is only in eleventh place (1\% of all countries' GDP (PPP) or US $\$ 27$ billion) (Science Report 2010; Battelle \& R\&D Magazine 2012).

Research investment has seen a rapid growth in emerging economies. In addition to the rapid development of R\&D in China, the Republic of Korea and Taiwan, representatives of the developing world such as Malaysia, Indonesia and Saudi Arabia started with a relatively small investment in R\&D (less than $1 \%$ of GDP), but intend to increase it over the next few years in order to consolidate the status of the states with an innovation-oriented economy (Battelle \& R\&D Magazine 2012).

To characterize the impact of R\&D and information technology development on global economic growth, the correlation coefficients have been calculated, as well as direct dependence between the numerical values of the indices of about 80 countries in the international rankings of innovative development and some selected indicators of economic development in 2012: 1) GDP per capita (the correlation value is in the range of 0.86 $0.92)$; 2) data on the volume of high-tech production per capita (in the range of $0.52-0.70$ ); 3 ) data on the volume of goods and services production in the ICT sector per capita (in the range of $0.79-0.88$ ) and 4) data on R\&D expenditure per capita (in the range of 0.81-0.91) (Rodionova 2013). The following conclusions were made: foremost, at present, countries with the highest level of socio-economic development are ready for a knowledgebased economy and widespread ICP usage. The leaders in the manufacturing of high-tech products are those countries which have placed knowledge and ICT at the service of the economy, so that they occupy leading positions in the global economy.

Geographical shifts in the global manufacturing industry

World industry is considered as a complex, hierarchically organized, polystructural system, or a complex of interconnected 
Table 1. Per-capita MVA at constant (2000) US\$

\begin{tabular}{|c|c|c|c|c|c|c|}
\hline regions & 1990 & 1995 & $\mathbf{2 0 0 0}$ & $\mathbf{2 0 0 5}$ & $\mathbf{2 0 1 0}$ \\
\hline World & 827 & 848 & 948 & 1036 & 1052 \\
\hline Developed economies & 3575 & 3722 & 4239 & 4548 & 4267 \\
\hline Developing economies & 171 & 211 & 254 & 321 & 430 \\
\hline Region/country & \multicolumn{4}{|c|}{680} & 711 \\
\hline Asia & 591 & 608 & 656 & 221 & 270 \\
\hline China & 130 & 159 & 177 & 480 & 820 \\
\hline Middle East and North Africa & 100 & 199 & 303 & 193 & 206 & 242 \\
\hline Sub-Saharan Africa & 30 & 26 & 28 & 30 & 35 \\
\hline CIS & 397 & 200 & 232 & 330 & 358 \\
\hline
\end{tabular}

Sources: Industrial Development Report, 2012. UNIDO. Vienna, Austria. 2012. Available from: http://www.unido.org [27 January 2013].

elements - the production units of nation-states, as well as transnational corporations (including multinational) and their subsidiaries. The industrial structures of each region (country or area) and the world as a whole are influenced by both the territorial and sectorial (intra-, inter-branch) division of labour (Rodionova 2010: pp.16-17).

Nowadays the production process in any country has become a part of global production. World industry, in its basic properties, already possesses the special qualities of a united system, while its global structure is morphologically broken.

Enhancements of all kinds of world transport and communications, as well as production activities of TNCs, contribute to the development of this process. The economies of many developing countries in recent decades have become more integrated into the global chain of added value production through accelerated methods of technology transfer and the availability of better access to markets.

In the global industry, in the last decade, the highest growth rates were observed in the production of communication tools (radio, television and other communication equipment), computer and office equipment, and electrical equipment.

Global industrial production is shifting to the developing countries as TNCs create production capacities there. Changes in the geography of industrial production on a global scale reflect the ever-increasing integration of national economies through trade liberalization, greater access to financial resources and increasing the flow of direct foreign investment (Rodionova 2012).

Previously, we analysed the dynamics of global industry (Rodionova 2009; Rodionova 2010, Rodionova, Kokuytseva 2010; Rodionova 2012; Rodionova 2013). Statistical analysis has shown that the share of developing countries in global industrial production has increased significantly over the past decade, including growth in the manufacturing sector (more than $35 \%$ in 2010) (United Nations Industrial Development Organization 2011). This trend has been retained until now - 35\% in 2012 (United Nations Industrial Development Organization 2013). From 1990 to 2010, production in the manufacturing industry grew at a rate of about $3 \%$ per year, and increased from US $\$ 4290$ to US $\$ 7390$ billion.

Analysis of the data presents not only the dynamics of the volume of manufacturing output in the world and separate developing and developed regions, but also shows the share of leading countries in the global industry. According to the data for
2012, growth in global industrial production declined in 2009 as a result of the global financial crisis, but in 2012, the growth rate was $2.2 \%$ (United Nations Industrial Development Organization 2013).

Meanwhile, China, the Asian NICs and some other countries (with priority on the development of manufacturing industries) have significantly strengthened their positions in the global economy. The volume of industrial output grew due to the fact that it relocated from advanced to emerging countries, such as China, India, Taiwan, Mexico, Brazil and other countries, which rapidly developed the industrial sector of their economy. In 1990 , the share of developed countries in global manufacturing output (in terms of value added) was $79.3 \%$, in $2005-72.7 \%$, and by 2010 their share had fallen to $64.4 \%$. In other words, the share of developing countries was constantly rising. At the same time (as was already mentioned) the number of highly economically developed countries had grown from 33 to 57 since 2000 and was replenished with such countries as the Republic of Korea, Malaysia, Singapore, etc. (United Nations Industrial Development Organization 2013). The share of emerging countries is much higher (if the geographical typology is used, i.e. the division of countries into developed and developing countries). From here on we use the countries' classification, adopted by UNIDO.

The level of industrial development can be evaluated by the index of production output per capita (table 1).

According to this indicator, UNIDO experts noticed some significant disparities in countries and regions of the world. Firstly, the U.S., China, Japan, Germany, the Republic of Korea, the United Kingdom, France and Italy are the leaders of global industry. China and South Korea are firmly settled on the top lines of the rating, ahead of almost all advanced countries of Europe. India, Taiwan, Brazil, Mexico and Turkey are further down the list of the leaders by manufacturing output. Russia accounts for only about $1 \%$ (table 2).

It is important to point out that the indicators of the leaders in the ranking seriously differ in the share in manufacturing related to GDP, manufacturing value-added (MVA) per capita, the share of manufactured goods in global exports, and others.

So, by volume of production, not only are China, the Republic of Korea and India ahead of Russia, but also Mexico, Turkey, Indonesia and Argentina. At the same time, Russia has a ten-fold gap from the leaders in terms of MVA per capita. 
MISCELLANEA GEOGRAPHICA - REGIONAL STUDIES ON DEVELOPMENT

Vol. $18 \cdot$ No. $1 \cdot 2014 \cdot$ pp. 31-36 • ISSN: 2084-6118 • DOI: 10.2478/v10288-012-0044-Z

Table 2. Value added of all manufacturing industries (MVA) in the leading countries of the world economy, 1995-2011

\begin{tabular}{|c|c|c|c|c|c|c|}
\hline \multirow{2}{*}{ Country } & \multicolumn{2}{|c|}{ Share of the world MVA, \% } & \multicolumn{2}{c|}{$\begin{array}{c}\text { Share of the world } \\
\text { manufactured export, \% }\end{array}$} & \multicolumn{3}{c|}{ MVA per capita, \$ } \\
\cline { 2 - 7 } & $1995^{*}$ & $\mathbf{2 0 1 1 * *}$ & $\mathbf{1 9 9 5}$ & $\mathbf{2 0 1 0}$ & 1995 & 2011 \\
\hline USA & 24.5 & 21.0 & 12.1 & 8.7 & 4327.0 & 5714.0 \\
\hline China & 5.1 & 17.4 & 3.3 & 13.0 & 254.0 & 1063.0 \\
\hline Japan & 20.4 & 10.9 & 8.7 & 6.1 & 7743.0 & 7374.0 \\
\hline Germany & 7.4 & 6.5 & 11.1 & 9.7 & 4311.0 & 7106.0 \\
\hline Republic of Korea & 1.9 & 3.4 & 2.9 & 4.0 & 2027.0 & 6046.0 \\
\hline
\end{tabular}

* at constant (2000) US\$

** at constant (2005) US\$

Sources: Industrial Development Report, 2012. UNIDO. Vienna, Austria. 2012. Available from: http://www.unido.org. [27 January 2013]; International Yearbook of Industrial Statistics. 2013. UNIDO, Vienna, 2013. P. 44-46.

Table 3. Share Change of Macroregions in Global Production of Separate Types of Manufactured Products, 1950-2010, (\%)

\begin{tabular}{|c|c|c|c|c|c|c|c|c|c|c|}
\hline \multirow{2}{*}{ Macroregions } & \multicolumn{2}{|c|}{ Steel } & \multicolumn{2}{c|}{ Fertilizers } & \multicolumn{2}{c|}{ Chemical fibres } & \multicolumn{3}{c|}{ Cars } & \multicolumn{2}{c|}{ Cement } \\
\cline { 2 - 13 } & 1950 & $\mathbf{2 0 1 0}$ & $\mathbf{1 9 5 0}$ & $\mathbf{2 0 1 0}$ & 1950 & $\mathbf{2 0 1 0}$ & 1950 & 2010 & 1950 & 2010 \\
\hline $\begin{array}{c}\text { Europe } \\
\text { (excl. USSR/CIS) }\end{array}$ & 31.9 & 12.4 & 52.5 & 11.5 & 47.1 & 7.1 & 13.7 & 23.5 & 43.7 & 7.7 \\
\hline USSR/CIS & 14.5 & 7.6 & 8.0 & 14.6 & 1.5 & 0.9 & 0.8 & 2.4 & 7.8 & 2.5 \\
\hline North America & 48.1 & 7.8 & 28.5 & 17.8 & 41.2 & 9.6 & 85.5 & 9.0 & 32.8 & 3.3 \\
\hline $\begin{array}{c}\text { Central and } \\
\text { South America }\end{array}$ & 0.5 & 3.2 & 1.6 & 3.4 & 1.9 & 2.7 & - & 6.0 & 4.7 & 4.1 \\
\hline Asia & 4.1 & 67.0 & 5.5 & 48.3 & 8.3 & 78.7 & - & 58.2 & 8.0 & 78.3 \\
\hline Africa & 0.4 & 1.3 & 0.7 & 3.6 & - & 0.9 & - & 0.6 & 2.1 & 3.8 \\
\hline $\begin{array}{c}\text { Australia and } \\
\text { South Pacific }\end{array}$ & 0.5 & 0.7 & 3.2 & 0.8 & - & 0.1 & - & 0.4 & 0.9 & 0.3 \\
\hline WORLD & 100 & 100 & 100 & 100 & 100 & 100 & 100 & 100 & 100 & 100 \\
\hline
\end{tabular}

Calculated by the author

Statistical analysis, presented by UN experts, leads to the conclusion that the global financial crisis of 2008-2009 more severely affected the industry of developed countries than that of developing countries. The crisis led to a decline in the industrial production of advanced countries, but the total industrial production in developing countries continued to grow (although chiefly due to China).

Peculiarities in the changes in distribution of some individual productions, which reflect complex migration processes in the global industry, are illustrated through the data presented in table 3.

Characteristics of changes in the distribution of some specific industries, reflecting the complex migration processes in the global industry, are characterized by the author (Rodionova, 2000; Rodionova, 2002; Rodionova, 2009, 2010, 2012, 2013, etc.).

In world industry the research on changing structure was carried out at the level of the seven geographical macro-regions: 1) North America (U.S., Canada, Mexico), 2) Central and South America, 3) Europe (Western and Eastern Europe), 4) former
USSR (now CIS-Commonwealth of Independent States), 5) Asia, 6) Africa, 7) Australia and Oceania.

Industrial construction was seen as a combination of the global industrial production of individual countries. The data for industrial production (mining and manufacturing) was analysed in terms of physical indicators by volume of production or weight of manufactured products. Changes in the level of industry concentration for 44 products (from 19 industry sectors in the extractive and manufacturing industries) were defined by the author through calculation and comparison of the share of the 3 (as well as 5 and 10) leading countries in total global industrial production during 1950-2010. As well as the variations, absolute increments and total growth rate of individual parts were calculated (quadratic coefficients of the "absolute" and "relative" changing structure) (Rodionova 2000, 2002, 2010, 2012).

Analysis of the data defined a changing structure at the national and regional level, leading to the conclusion that in the second half of the XX century and the beginning of the XXI century there were significant changes in the distribution of 
production capacities in different sectors of the manufacturing industry globally. In all sectors included in the research, there was a regrouping of forces, the redistribution of industrial production both at the national and regional level. The most important trend is the increase in Asia's share of the global volume production of most industrial products.

Significant territorial changes have been identified in major industrial sectors.. However, it is to be noted that they have different natures. In some industries, changing structure may be considered cardinal, in others, ordinary. In other words, the volume of production grew in all sectors, although processes of varying intensity occur. The particulars of the geographical changes taking place were in four sector groups:

1) Extractive industries, many of which are characteristic of cyclical migration of production. Cycles of "transfer" of the centres of gravity of mining from developed countries to developing countries were traced - and in some cases, conversely.

2) Manufacturing industries in which the "direct migration" of production capacity was revealed (ferrous and non-ferrous metallurgy, the production of construction materials, sectors of basic and organic chemicals, the textile and food industries etc.). It is as though the more developed countries previously "washed out" the traditional industrial production of the industrial sector for the economy. In this case, the reduction of volume production in developed countries takes place at the same time as the growth of production in developing countries (mainly by China and by countries of the "semi-periphery" of the world economy). The system of intra-country relations in these industries was replaced by a system of macro-regional and global connections.

3) Certain manufacturing industries in which there is "indirect migration" of production capacity from one region to another. Mass production of many kinds of standardized production is characterized by a movement to global placement by expanding the market space in a globalizing world economy, technical and technological standards in production and consumption through the use of cheap labour. These kind of migration processes have been observed in the machine industry (production of cars, TVs, refrigerators, tape recorders, computers, washing machines etc.), in the chemical industry (including the large group of polymeric materials), in the textile and food industries.

4) The output of sectors, sub-industries and certain manufacturing industries which is actually not prone to migration processes. These are the knowledge-intensive industries biotechnology, the advanced manufacturing electronics industry, aerospace manufacturing etc. - the placement of which is adapted to R\&D. These centres occur in economically developed countries, as does the production of expensive (exclusive) goods (for example, some of the light industry), or environmentally responsible products (the food industry), etc., which are the speciality symbol of the economically advanced states in the world economy.

It is important to emphasize that production volumes grew in all analysed branches, but the processes were of varying intensity. This thesis is illustrated by the maps presented in the handbook "Socio-Economic Geography of the World: a Reference Manual" (Kholina, Naumov, Rodionova 2009) and "Geography. Profile Level: Atlas" (Kholina, Naumov, Rodionova 2013).

\section{Conclusions}

Profound changes are taking place in all structures of the global industry. Its industrial structure is constantly diversifying under the influence of STP - scientific and technical progress, the variety of forms of public production organization is modifying, and interdependence on the world markets of labour, capital, goods and technologies is increasing. At the same time, both at the national and at the regional and global level, there are shifts in the distribution of production capacity, i.e. the spatial structure of global industry is changing.

The industrialization process on a global scale is ongoing; changes in the distribution of extractive industries and manufacturing on the macro-regional level are very significant.

The industrial world has become three-pole. The Asian vector of global industrial development is clearly fixed, but, from the point of view of the spatial organization of industrial production, on a global level, the differences along the "North" - "South" border (developed - developing countries) still persist. However, the share of developing countries in global industrial production and industrial exports has been increasing steadily, and this trend will be maintained in the future.

The countries of East and South-East Asia are serious competitors for many major world exporters. China is moving to the position of world leader in industry and industrial exports, despite the global and domestic economic crisis.

The global financial crisis of 2008-2009 brought the world economy to a global recession, but mostly it affected the volume of industrial production and exports of developed countries. However, the general trends in global industry and the main directions of spatial changes in the Asian region are preserved.

\section{References}

Battelle \& R\&D Magazine 2012, Global R\&D Funding Forecast. Available from: <http://battelle.org/docs/default-documentlibrary/2012_global_forecast.pdf>. [15 January 2013].

Battelle \& R\&D Magazine 2013, Global R\&D Funding Forecast. Available from: <http://www.battelle.org/docs/default-documentlibrary/2013-R-and-D-Funding-Forecast. pdf?sfvrsn=4>. [17 January 2013].

Galkin, MA \& Rodionova, IA 2013, 'National innovation systems in the conditions of R\&D internationalization' in Econ-inform, ed IA Rodionova., Moscow. Available from: <http://weblocal.rudn.ru/web-local/prep/rj/files.php?f=pf_16dec415707 25374cb8355febc2dbdd3>. [2 September 2013].

Gorkin, AP 2012, Geography of postindustrial industry, Oikumena, Smolensk.

Industrial Development Report 2012. UNIDO. Vienna, Austria. Available from: <http://www.unido.org>. [27 January 2013].

International Yearbook of Industrial Statistics. 2013. UNIDO, Vienna, pp. 44-46.

Kholina, VN, Naumov, AS, Rodionova, IA 2009, Socio-Economic
Geography of the World: a Reference Manual, Drofa, Moscow.

Kholina, VN, Naumov, AS, Rodionova, IA 2013, Geography. Profile Level: Atlas, Drofa, Moscow.

Pelyasov, AN 2012, Synergy in space: regional innovation systems, clusters and knowledge spillovers, Oikumena, Smolensk. Available from: <http://www.ecoross.ru/files/ books2012/Pelyasov,\%20ed.,\%202012.pdf>. [22 May 2013].

Rodionova, IA 2012, 'World manufacturing industry: structural and spatial shifts', Analele Universitatii din Bucuresti (Romania). Geografie, LXI/2012, pp. 55-67. Available from: <http://www.annalsreview.geo.unibuc.ro/2012/Rodionova. pdf>. [10 September 2013].

Rodionova, IA \& Kokuytseva, TV 2010, 'Structural changes of world industry in post-industrial society and structural shifts in the world high-tech production allocation' in Processes of Transformation of Industry and Services in selected countries, eds Z Zioło and T Rachwał., Warsawa-Krakow, no. 16, pp. 38-51. Available from: <http://prace-kgp.up.krakow. $\mathrm{pl} /$ article/view/222/138>. [10 September 2013]. 
Rodionova, IA \& Sholudko, AN 2008, 'The transformation of labor and employment in post-industrial society', Bulletin of Geography: Socio-economic series, no. 9. pp. 2131. Available from: <http://www.degruyter.com/view/j/ bog.2008.9.issue--1/v10089-008-0002-x/v10089-0080002-x.xml?rskey=VxM0UP\&result=1>. [10 May 2013].

Rodionova, IA 2000, Makrogeografiya industry of the world. Textbook for university students. Moscow, Moscow High School.

Rodionova, IA 2002, Industry of the world: territorial shifts in the second half of the twentieth century, Moscow.

Rodionova, IA 2009, World economy: structural changes and trends (from the second half of XX to the beginning of XXI century), Moscow.

Rodionova, IA 2010, World economy: industrial sector, Moscow.

Rodionova, IA 2013, 'Competitiveness of countries in the world innovation economy: East-Central Europe and Russia', Quaestiones Geographicae 32(2), Bogucki Wydawnictwo
Naukowe, Poznań, pp. 15-24. Available from: <http:// geoinfo.amu.edu.pl/qg/current/quageo-2013-0010.pdf.> [10 May 2013].

Science Report 2010, The Current Status of Science Around the World. NY, UNESCO. Available from: <http://stats.uis. unesco.org/unesco/ReportFolders/ReportFolders.aspx?IF_ ActivePath=P,54\&IF_Language=eng $>$. [15 January 2013].

United Nations Industrial Development Organization 2011, Industrial energy efficiency for sustainable wealth creation. Available from: <http://www.unido.org/fileadmin/user_media/ Publications/IDR/2011/UNIDO_FULL_REPORT_EBOOK. pdfl>. [16 May 2013].

United Nations Industrial Development Organization 2013, Industrial Yearbook of Industrial statistics. Available from: <http://www.unido.org/resources/publications/flagshippublications/international-yearbook-of-industrial-Statistics. html>. [19 May 2013]. 